\title{
Public Spaces in Local Places 1
}

\section{Maxine Greene}

\author{
Teachers College, Columbia University
}

Doubts are accumulating with regard to the uses of rational discourse in the rule-governed sphere once thought of as the public space. There autonomous individuals presumably resolved disagreements, worked out consensus, and devised plans of action for the benefit of those they represented and in the light of logically derived norms. Communicating within the same universe of meaning, they functioned apart from the domains of private life: the domains of women, feeling, subjectivity. Today the boundaries are no longer clear. Words, images mean variously, as the recognition grows that language does not refer to phenomena in some external "reality." Multiplicity, relativism, contingency: these are the watchwords. The very notion of representation is challenged; the idea of consensus has come to seem illusory; there are no essences to be sought within the newly acknowledged diversity. In their lived lives, people feel their own voices overwhelmed by technical talk or the formulas of the media. They turn inward, many of them, withdrawing from what lies beyond their immediate, everyday concerns. Surrounded by simulacra, artifacts, artifices, they grope for a sense of actuality, of particularity. Powerlessness, passivity, and a kind of despair shroud many of them. As Percy's (1961) narrator says in The Moviegoer: "Not to be onto something is to be in despair."

How, under such circumstances, can situations be created in which persons consciously choose to appear before one another in the open, to come together in "speech and action," as Arendt (1985) says, as the best they know how to be? How can they be moved to reach out from their own distinctive vantage points and constitute something they cherish and hold in common, something that will always be in the making, that can always be renewed? Or, to put it in Dewey's $(1934,1954)$ terms, how can situations be created in which persons overcome their apathy enough to take heed of the consequences of certain modes of behavior, to take care of and look out for them? Consequences of particular actions (like the abuse of a child, for instance, or an instance of homelessness, or an understaffed school) ought to "call a public into being" if they are attended to, if they are named. And it is when an articulate public comes into being that a space opens where communication can take place and action can be taken, action that might repair, might even transform. 
We realize now that the diverse human beings who might compose such a public have in some manner to be awakened to their being in the world. I am reminded of Virginia Woolf (1957) writing of "shocks of awareness," of the need to disentangle from the "cotton wool of daily life." I am reminded as well of Camus's (1948) novel The Plague and of the shock that afflicted the perfectly ordinary and habit-ridden town of Oran when the pestilence struck. The primary aim of the town had been "doing business"; and the epidemic caught people as so unprepared that they were silenced and thrust into isolation, or wholly private concerns. Then a man named Tarrou came to town and began organizing sanitary squads to fight the plague (for which there was no known cure); and those squads brought into being what can only be described as a public space. They "enabled our townsfolk," says the narrator, "to come to grips with the disease and convinced them that, now that plague was among us, it was up to them to do whatever could be done to fight it. Since plague became in this way some men's duty, it revealed itself as what it really was; that is, the concern of all." If we think of the speechlessness, the withdrawals, the violence, the violations of our time as modes of plague, we realize that if they are to appear as "the concern of all" they have to be chosen or named as a concern by each person from his or her lived location in the world. There is no way of asserting any longer that something "revealed itself as what it really was." And if fighting the plague did indeed become "some men's duty," it was only because those men created themselves as plague-fighters, decided that that would be the way they were in the world.

There is a reminder in Merleau-Ponty's (1964) essay "Eye and Mind" that suggests what is required if this is to occur. He recalls to his reader science's bias of treating everything "as though it were an object-ingeneral," as though it meant nothing to us and yet was predestined for our own use. And then:

Scientific thinking, a thinking which looks on from above, and thinks of the object-in-general, must return to the "there is" which underlies it; to the site, the soil of the sensible and opened world such as it is in our life and for our body - not that possible body which we may legitimately think of as an information machine but that actual body I call mine, this sentinel standing quietly at the command of my words and my acts.

He speaks then of the associated bodies brought forward with his body, the "others" along with whom he haunts "a single, present, and actual Being." Without a return to the "there is," to the world "such as it is in our life and for our body," persons are likely to be left with the "Other's" definition not only of themselves but, of a world (or a society, or a plague) ascribed a fictitious totality, a groundless objectivity. 
Situated, conscious of their situatedness, persons come to realize the provisional character of their perceiving. Being with others in what they can feel to be a plurality, there can be no predetermined consensus, no filling of the space. There are discontinuities; there are openings; there is always an incompleteness; there are meanings to be achieved. Arendt (1985) writes with respect to the public space that "the reality of the public realm relies upon the simultaneous perception of the innumerable perspectives and aspects in which the common world presents itself and for which no common measurement or denominator can ever be devised." Saying that, she summons up by implication the vast differences in human experience, in human graspings of the world. Literature, perhaps, is the richest source for coming in touch with differences in this sense, with what will always escape "common measurement." I think of the narrator of Ellison's (1952) Invisible Man, whose invisibility is attributed to a condition of the eyes on the part of those who look at him. I think of Kincaid's (1990) Lucy, the Antiguan young woman who read Wordsworth's poem on daffodils in the Queen Victoria Middle School and thought that if she ever came upon daffodils she would want to cut them down with a scythe. I think of the Chinese railroad workers' vision of this country in Kingston's (1989) China Men. I think of Virginia Woolf (1976) writing about the "sudden splitting of consciousness" surprising a woman when she realizes that "from being the natural inheritor of her civilization, she becomes, on the contrary, outside of it, alien and critical." I think of Ozick (1989) talking about the uses of metaphor in "imagining the familiar heart of the stranger."

The perspectival attitude of mind, open to limitations and to possibilities, strains toward the common, opens to the common. The very straining toward what might become the kind of knowing that brings about a change in lived reality. It may depend on the plurality of persons coming together, not as what they are but as who they are, in what Arendt calls an "agent-revealing" way. That may signify remaining in touch with life narratives, with stories; it may mean being in touch with what Habermas (1973) calls each one's "self-formation." The dialogue that goes on among situated participants cannot but deal with worldly and practical interests, Arendt reminds us. These intereststhe setting up of a caring group for an AIDS victim, the launching of a literacy program, the preparing of a children's art exhibit-lie between people and relate and bind them together. It should be stressed, although Arendt does not do so, that the discourse of objective expertise (or instrumental rationality) should not dominate when it comes to the definition of those interests or the demarcation of the space. The plurality, as viewed in the present context, ought to be inclusive of those who are in some manner marginal, those not necessarily acquainted with academic projections, those who might be directly af- 
fected by the social need or deficiency that is the occasion for the coming together. Clearly the voice of the adolescent mother sounds different from that of the social worker when abortion or child care is being discussed. The story of the recent arrival from Guatemala differs enough from the Vietnamese story or the oppressed Puerto Rican woman's narrative to indicate the importance of several kinds of mediation in what we now might call a public space. Geertz (1983) reminds us of the significance of "making it possible for people inhabiting different worlds to have a genuine, and reciprocal impact upon one another." The visions (even the approaches to teaching reading or caring for infants) may be "not wholly commensurable," as he says; but it remains important to accept the differences, try to understand what they are, and attempt to devise a vocabulary of practice through which the various members of the plurality can name what lies before them, as they give understandable accounts of themselves. Again, the preoccupation here has to do with the consequences of often privatized decisions (or real estate owners, perhaps, city officials, churchmen, welfare agencies) and the choice to attend to those consequences for the sake of healing, for the sake of repair.

Emphasizing the relation between the disclosure of various subjects in the plurality and the intercourse that takes place when an in-between" begins slowly to arise, Arendt (1985) suggests that the objective interests are often overgrown with another in-between. This one owes its origin to people's acting and speaking directly to one another, for all their differences. It is a subjective in-between that is intangible. Unlike the other in-between, it will not leave behind a counseling center, a tutoring program, a prekindergarten, a clinic. "But, for all its intangibility, this in-between is no less real than the world of things we visibly have in common. We call this reality the "web of human relationships,' indicating by the metaphor its intangible quality." Ozick's (1989) reference to the "familiar heart of the stranger" retarns, as the reader wonders whether such a "web" can indeed bring together a plurality of strangers. Ignatieff (1984, focusing on the "needs of strangers") offers some help when he talks about the uses of a language of needs rather than a language of rights, which does not include fraternity, love, belonging, dignity, and respect. He wants to hear a language of the good that defines human nature in terms we lack, that treats us in terms of potentials, as forever incomplete.

This connects with the perspectival, provisional view suggested above. It is a view that constructs a space that is unfinished, marked by absence as much as presence. Moreover, the participants in the plurality can only see aspects, profiles of those around, even as they hear intimations, slivers of shifting meanings, murmurs of possible truths. The only human goods that can be specified, says Ignatieff (1984), are the prerequisites for any human pursuit. "If we need love, 
respect, fraternity, it is not because these are required for the realization of our essential natures, but because whatever we choose to do with our lives, we can scarcely be reconciled to ourselves or to others without them." We need love, he adds, "for the connection, the rootedness, it gives us with others." And this may be part of what Arendt (1985) has in mind when she speaks of that web. Indeed, we may find ways of integrating this into our notions of community and the emergent public. Only someone with a consciousness of agency, only a subject can choose to disclose herself or himself to others in an open space. Only a person who is fully present and subjectively alive can risk the break with anchorage that might open a space for choice and dialogue, where "reality" can no longer be frozen in some context-free discourse that volutes lived experience in its multiple forms. Nietzsche (1958) comes to mind with his warning that none of this can happen under conditions of "closet air, closet ceilings, closet narrowness." Revealing themselves, working toward an articulateness of their own, persons may gradually develop a consciousness of agency; and if they do, it may be that a new power will spring up in the public space created, what Foucault (1980) calls a "relationship of power" among awakened human agents. It may become a power with effects on present actions and unpredictable effects on actions taken in time to come. Fields have to be opened, he says, for new responses and "possible inventions," something quite different from the predictable, the calculated, the forever normalized.

To think of local places in connection with all this is to summon up the images of schools that can allow for multiplicity and risk, and for particularism as well. To initiate the kinds of places where the technical rules and the frozen forms can be set aside, where the multiplicity of youthful voices can be truly heard, there must be (as Geertz, 1983, says) not only a degree of "local knowledge" but "feeling for immediacies." Indeed, the coming together can begin where things are concrete and to some degree familiar to all. There are schools today, small schools, "alternative schools" within the system, where the days begin with "family groups" meeting and recounting what has been happening in their homes since the day before. Each one, presenting her or his story, sharing the story, somehow defining herself/himself and the ends (even the shrouded ends) she/he has in view, is released to reject the predefined school reality, even what is called "school knowledge." Once student spontaneity is nurtured, once young people are offered opportunities to say, perhaps to sing, to paint, to dance, new orders take form in their experience, new possibilities open; and what is offered in the way of subject matter can be grasped more easily from a lived location, grasped not as a given, but from a point of view.

The point of view must be heeded, granted its integrity. In some sense, it must be cherished in a way a child can understand, even as the 
child's questions (like the teacher's questions) can be encouraged and even loved. Cared for, authentically cared for, the young, viewing themselves as beginners, can move from the near to what is closer to the horizon without the risk of losing themselves in the large abstractions so often confused with official certainties. Recollections of landscape paintings, often romantic landscape paintings, help somehow to shed light: they are paintings often with visions of pathways, roads leading out from the home place, moving along streams, reaching toward the hills, sometimes circling back. Those roadways provide metaphors as children are offered opportunities (and languages, sometimes, tricks of the trade) to teach themselves as they risk moving on to a wider world. And it may be that, as they move, they may discover how discourse, live and diverse discourse, can open up new worlds.

Local knowledge, a local coming together ought to help children defend against acquiescence in global solutions, tempting though they may be. For them, like for their teachers, learning is contextual, situationspecific; and it is grounded in the primordial landscapes in which life and orientation to the world begin. Clearly not all the configurations are the same, even as not all stories unfold in the same way; and, in the local spaces, translations are sometimes sought. It may be important to realize that we cannot ever precisely know what things mean to others or for others unless it is already known to both of us, as Tyler (1986) says, and "thus needs no translation, but only a kind of reminding." He makes the point that there is no "originating text" nor any objective reality preceding the dialogue or (in his case) the ethnography. "It creates its own objects in its unfolding and the reader supplies the rest." This may become an appropriate metaphor for a teacher, who may come to see that a newcomer child will invent herself or himself, create her or his meanings as that child lives and grows. The teacher, like the reader, interpreting against her own lived world may supply as much of the rest as is possible.

This is only likely to happen, of course, in atmospheres free of the impersonality of hierarchies and the nameless authority that inheres in them. It is obvious enough that power diffused this way creates passivity, compliance, and the erosion of the sense of agency. Goodlad (1979) once said that parents almost everywhere "would take power from the more remote, less visible, more impersonal authorities heading the system and place it in the hands of the more visible, more personally known, close-at-hand staff of the school and parent groups close to the school." We are beginning to see an extension of local control, of "site-based management," of collaborative arrangements; and at once we are beginning to hear an infusion of language that escapes the familiar technicism of educational talk. Without the patterning that obscures contesting hopes and warring desires, conflicts emerge; but it increasingly seems that such conflicts are what might 
give rise to articulations of what diverse persons expect education to be. Again, it is a question of honoring the range of vantage points, each one ascribed its own integrity, and working (as in the public space) for an always incomplete in-between. Common purposes and shared commitments, even those that incarnate what we value in our democracy, cannot be prescribed or legislated into being. Once again, it is a matter of devising the kinds of local situations, in meeting halls and classrooms and even school corridors, where diverse individuals in their plurality can come together and decide how they choose to remain together, against what memories, and in accord with which norms.

A wide-awakeness has to be achieved if this is to happen; and there may have to be deliberate efforts made to awaken, to arouse. I think of Nietzsche (1958) writing about rekindling "drowsing passions," about "joy in the new, the daring, and the untried." He went on to talk of giving style to character, creating a life "by long practice and daily labor" as a work of art. He had form in mind and the constraints needed if freedom is not to be arbitrary ("fantastic, disorderly") or simply self-indulgent. This suggests the degree of consciousness, of care that must accompany the achievement of freedom. It is a degree of consciousness that may give rise to a sense of oughtness, of responsiveness to agreed-upon norms. A public space cannot exist without shared commitments to regard for the integrity of diverse perspectives, to moral equality, to decency, to a kind of rational passion that might move participants to reach beyond themselves. It is not only that values may be created when persons come together in this manner. It is that a richer singularity may be attained by each one choosing to live by beliefs (or by principles) that allow the space to be, even as a richer conception of what is held in common may emerge from persons speaking in their own voices, acting on their own initiatives.

If such spaces of dialogue can extend far enough and connect to other spaces, if diverse human voices can become more and more audible, if more and more publics can be formed and become articulate, the mystifying languages will become in some manner transparent. We will hear the sounds of desire as we open ourselves to more and more stories; and we will hear articulations of new visions as possibilities open, as people begin to recognize the incompleteness of things. If the sense of possibility is really to be enhanced, of course, the spaces we create in local places must allow for imagination as well, for that power of cognition that discloses alternative realities, unconceals what is not yet. The arts must be present in those spaces; and efforts must be undertaken to engage persons with the range of works of art. To be literate in this fashion is to be able to crack the codes that have kept secret so many visions of freedom and fulfillment, to allow created worlds-a Cezanne landscape, a Toni Yorrison novel, a Paul Taylor dance performance, a Mozart quintet, a Woody Allen film-to emerge 
in experience, recognized, intended, deeply grasped. Acts of imagination uncouple persons from the routine and the taken for granted. They provoke them to move into new places in experience, to open windows, to hear, and feel and come alive. Works of art can only be achieved by means of personal agency, because each one who attends has to be there in person, letting her or his own energy go out to the work, bringing it into being for herself or himself and through an act of decision, a free act of choice. At once, each one can only personally engage with a work that has a historical and public presence, something that has found and may still find other realizations. The more variously it is interpreted, the more multilayered it becomes, especially if the one engaging with it at a given moment is enabled to become aware of what others have heard and seen-or are hearing and seeing at the same moment. Something vital, something palpitant, something common enters the human world at times like this; and the world has, to an extent, been changed. Stevens (1982) speaks of a blue guitar as a symbol for imagination, the blue guitar "that does not play things as they are. Things as they are are changed upon the blue guitar." And, later, the guitarist says, "You as your are? You are yourself. The blue guitar surprises you." Surprise, yes, and the unpredictable. Without these, possibility dims.

If the local place extends outward through the use of imagination, if immediacies and particularities become palpable there, if individuals in their becoming reach toward one another, the shapes of a public-inthe-making may emerge. The discourse of that public-in-the-making may gradually become audible in changing spaces where persons are willing to appear before one another-willing as well to engage in dialogue, to accept responsibility, to choose themselves, to construct a world. It lies ahead; it all lies beyond. The poet says it best. Here is Elizabeth Bishop (1983):

The year's doors open like those of language, towards the unknown. Last night you told me: tomorrow We shall have to think up signs, sketch a landscape, fabricate a plan on the double page of day and paper. Tomorrow, we shall have to invent, once more, the reality of this world.

Note

1. This is the original text of a symposium lecture presented at the 1992 AERA annual conference in San Francisco.

References

Arendt, H. (1985). The human condition. Chicago: University of Chicago Press.

Bishop, E. (1983). January First. In The complete poems. New York: Farrar Straus and Giroux.

Camus, A. (1948). The plague. New York: Knopf.

Dewey, J. (1934). Art as experience. New York: Minton Balch.

Dewey, J. (1954). The public and its problems. Athens, GA: Swallow Press.

Ellison, R. (1952). Invisible man. New York: Signet Press. 
Foucault, M. (1980). Power/knowledge: Selected interviews and other writings.

Brighton: Harvester Press.

Geertz, C. (1983). Local knowledge. New York: Basic Books.

Goodlad, J. (1979). What schools are for. Bloomington: Phi Delta Kappa Educational Foundation.

Habermas, J. (1973). Theory and practice. Boston, MA: Beacon Press.

Ignatieff, M. (1984). The needs of strangers. London: Chatto \& Windus.

Kincaid, J. (1990), Lucy. New York: Farrar Straus Giroux.

Kingston, M.H. (1989). China men. New York: Vintage International.

Merleau-Ponty, M. (1964). The primacy of perception. Evanston, IL: Northwestern University Press.

Nietzsche, F. (1958). The gay science. In W. Kaufmann (Ed.), The portable Nietzsche. New York: Viking Press.

Ozick, C. (1989). Metaphor and memory. New York: Knopf.

Percy, W. (1961). The moviegoer. New York: Knopf.

Rabinow, P. (1984). The Foucault reader. New York: Pantheon Books.

Stevens, W. (1982). The collected poems. New York: Vintage Books.

Tyler, S.A. (1986). Post-modern ethnography: From document of the occult to occult document. In J. Clifford \& G.E. Marcus (Eds.), Writing culture. Berkeley: University of California Press.

Woolf, V. (1957). A room of one's own. New York: Harcourt Brace \& World.

Woolf, V. (1976). Moments of being. New York: Harcourt Brace Jovanovich. 